\title{
Megameatus Intact Prepuce and Associated Anomalies
}

\author{
Megameatus İntakt Prepisyum ve Eşlik Eden Anomaliler
}

\author{
Gunay Ekberli, $\odot$ Ufuk Ateş, $\odot$ Sumeyye Sozduyar, $\odot$ Anar Gurbanov, $\odot$ Gulnur Gollu Bahadır, \\ $\triangle$ Meltem Kologlu, $₫$ Aydın Yagmurlu, $\odot$ Huseyin Dindar, $\odot$ Ahmet Murat Cakmak
}

Ankara University School of Medicine, Department of Pediatric Surgery, Ankara, Turkey

\begin{abstract}
Objective: Megameatus intact prepuce is described as subset of megalourethra or distal hypospadias by several authors. Despite suggested different operative techniques, some authors prefer not to operate this variant of penile anomaly. We aimed to evaluate 31 patients operated due to megameatus intact prepuce and associated anomalies.

Material and Method: Thirty-one patients operated between 2008-2018 for MIP were evaluated retrospectively. All data were collected from hospital records. Patient age, application reasons, raphe anomalies, associated genitourinary and extra genitourinary pathologies, operative techniques, and postoperative complications were analyzed.

Results: Mean age was 50 months (8-128 months). Ten of the patients had raphe anomalies. Genital raphe hyperpigmentation was seen in 1 patient, raphe deviation and bifurcated raphe was seen in 6 and 3 patients respectively. Genitourinary anomalies were detected in 7 patients, bilateral undescended testes in 1 patient, penile chordee in 2 patients, ureteropelvic junction obstruction in 2 patients, penoscrotal web in 1 patient, nocturnal enuresis in one patient. Tubularized incised plate urethroplasty (TIPU) $(n=5)$, tubularized urethral plate urethroplasty (TUPU) $(n=16)$ and meatoplasty $(n=10)$ were the operative techniques.

Conclusion: Co-occuring raphe anomalies should arise awareness of MIP among the clinicians who are engaged with the children's medical conditions and also the possible anomalies especially in the societies which circumcision is not traditionally required. Further studies with large number series needed for better understanding of this pathology.
\end{abstract}

Keywords: Megameatus intact prepuce, associated anomalies
Öz

Amaç: Megameatus intakt prepisyum, bazı yazarlar tarafından megalouretranın veya distal hipospadiasın alt kümesi olarak tanımlanmaktadır. Önerilen farklı ameliyat tekniklerine rağmen, bazı yazarlar bu penil anomali varyantın opere etmemeyi tercih etmektedirler. Megameatus intakt prepisyum nedeniyle opere edilen 31 hasta ve eşlik eden anomalilerini değerlendirmeyi amaçladık.

Gereç ve Yöntem: 2008-2018 yılları arasında MiP nedeni ile ameliyat edilen 31 hasta retrospektif olarak değerlendirildi. Tüm veriler hastane kayıtlarından toplandı. Hasta yaşı, başvuru nedenleri, raphe anomalileri, eşlik eden genitoüriner ve genitoüriner sistem dışı patolojiler, operatif teknikler ve postoperatif komplikasyonlar analiz edildi.

Bulgular: Ortalama yaş 50 ay (8-128 ay) idi. Hastaların 10\'unda rafe anomalisi vardı. Genital raphe hiperpigmentasyonu 1 hastada, raphe deviasyonu ve bifürkat raphe sırasıyla 6 ve 3 hastada görüldü. Bir hastada bilateral inmemiş testis, 2 hastada penil kordi, 2 hastada üreteropelvik bileşke tıkanıklığı, 1 hastada penoskrotal web, bir hastada nokturnal enürezis olmak üzere toplam 7 hastada genitoüriner sistem anomalisi saptandı. Tubularized incised plate urethroplasty (TIPU) $(n=5)$, tubularized urethral plate urethroplasty (TUPU) $(n=16) v e$ meatoplasty $(n=10)$ uyuglanan cerrahi tekniklerdi.

Sonuç: Eşlik eden rafe anomalileri özellikle sünnetin gerekmediği toplumlarda megameatus intakt prepisyum ve olası anomalileri açısından çocukların tıbbi koşulları ile ilgilenen klinisyenler arasında farkındalık oluşturması gerekir. Bu patolojinin daha iyi anlaşı ması için çok sayıda seri ile daha ileri çalışmalar gereklidir.

Anahtar Kelimeler: Megameatus intakt prepisyum, eşlik eden anomaliler 


\section{INTRODUCTION}

Megameatus intact prepuce (MIP) was described for the first time by Juskiewenski et al. ${ }^{[1]}$ and reported to be a variant of anterior hypospadias by Duckett and Keating. ${ }^{[2]}$ Some authors prefer to categorize MIP as a subset of megalourethra. ${ }^{[3]}$ Deep groove, non-closed glans with wide navicular fossa which causes large calibre, thin corpus spongiosum, coronal or subcoronal wide-mouth meatus, circumferential and normally constructed prepuce and no chordee are the characteristic components of MIP. ${ }^{[3-6]}$ MIP is not a uniform anomaly. Meatus may be glanular or coronal and rarely in distal shaft localization combined with characteristic components described above. ${ }^{[7,8]}$ Reported prevalence of MIP is 1 in 10.000 and may present $3 \%-6.8 \%$ of hypospadias cases. $[5,7,9,10]$ There are different embryological explanations for MIP development. It is thought to be due to maldevelopment of the glanular epithelial folding ${ }^{[2,11]}$ Another theory which was proposed by Nonomura et al. ${ }^{[12]}$ is the one that explaining the development of MIP by ischemic or compressive changes that effects normal urethra after it's complete closure.

Diagnosis of MIP is challenging because of intact prepuce. It is impossible to diagnose MIP antenatally either. ${ }^{[8,13]}$ Mostly MIP is discovered during circumcision. ${ }^{[1,3]}$ Because of the circumferentially intact prepuce patients or families do not have any clues to the anomaly. After retraction or circumcision, surgeon should give brief explanation to the parents if MIP is diagnosed. Otherwise there is a possibility of surgeon to be accused of causing the defect. ${ }^{[3]}$ Primary goal of MIP surgery is to obtain cosmetically favorable look because MIP does not affect patient's micturition and sexual physiology. ${ }^{[14,15,20]}$ So there is still controversies about whether to operate or not the MIP cases. ${ }^{[16]}$

The distinct anatomical features of MIP, challenging surgery, and unfavorable results led surgeons to describe different surgical techniques like modified glans approximation procedure (GAP), pyramid procedure, modified Mathieu operation and tubularized incised plate urethroplasty (TIPU). $[1,7,12,17,18]$

Anatomical features of the patient should be noticed individually before surgery. Circumcised MIP patients are the most important group in this anomaly. Lack of the Dartos tissue and prepuce can make MIP surgery more complicated than the uncircumcised group. ${ }^{[6]}$

The distinct anatomical features, different techniques for repair, obscure embriological theories, even different entitles makes MIP a unique penile anomaly. Our aim is to evaluate the results of available techniques and the additional anomalies in MIP patients in the presented study.

\section{MATERIAL AND METHOD}

Thirty-one patients operated between 2008-2018 for MIP were evaluated retrospectively. All data were collected from hospital records. Patient age, application reasons, raphe anomalies, associated genitourinary and extragenitourinary pathologies, operative techniques, and postoperative complications were analyzed. Patients were detected during physical examination prior or during to traditional circumcision or referred as distal hypospadias. Especially fimotic preputiums are not retracted prior to circumcision and as a result of this 5 MIPs were detected during circumcision. The study was carried out with the permission of Ankara University Clinical Research Ethics Committee (Permission granted: 01.09.2020, Decision no: i7444-20).

\section{RESULTS}

Mean age was 50 months (8-128 months). Ten of the patients had raphe anomalies. Genital raphe hyperpigmentation was seen in 1 patient, raphe deviation and bifurcated raphe was seen in 6 and 3 patients respectively. Genitourinary anomalies were detected in 7 patients, bilateral undescended testes in 1 patient, penile chordee in 2 patients, ureteropelvic junction obstruction in 2 patients, penoscrotal web in 1 patient, nocturnal enuresis in one patient (Table-1). Tubularized incised plate urethroplasty (TIPU) ( $n=5)$, tubularized urethral plate urethroplasty (TUPU) $(n=16)$ and meatoplasty $(n=10)$ were the operative techniques. After correction of MIP all of the children were circumcised and feeding tube or Zaont's catheter were used for drainage. Wound dressings were the same as in distal hypospadias repair with sterile gause with antibiotic ointment and removed on the fifth day of the surgery. Catheter removal was on the seventh day of surgery. Associated anomalies like penoscrotal web, bilateral undescended testes and penil chordee were operated at the same time with MIP repair. Fistula was detected in one patient. This patient was in TUPU repair group and fistula was closed six months after initial operation.

\section{DISCUSSION}

Megameatus intact prepuce is not a uniform anomaly. According to our results we offer careful examination of each patient referred for traditional circumcision. Raphe anomalies can be leading point for MIP suspicion. Despite existence of several techniques for repair each patient's anatomy should be evaluated carefully before the operation. Except one complication in TUPU group all operative techniques seems to be prosperiousprosperous in our MIP patient group. TIPU, TUPU and meatoplasty are suitable operative techniques for MIP.

\begin{tabular}{|c|c|c|c|c|c|c|c|}
\hline \multicolumn{3}{|c|}{ Raphe anomalies $n=10$} & \multirow[b]{2}{*}{ UPJO } & \multirow[b]{2}{*}{ Undescended testes } & \multirow[b]{2}{*}{ chordee } & \multirow[b]{2}{*}{$\begin{array}{c}\text { Penoscrotal } \\
\text { web }\end{array}$} & \multirow[b]{2}{*}{$\begin{array}{c}\text { Nocturnal } \\
\text { enuresis }\end{array}$} \\
\hline $\begin{array}{l}\text { Hyperpigmented } \\
\text { raphe }\end{array}$ & Deviated raphe & $\begin{array}{l}\text { Bifurcated } \\
\text { raphe }\end{array}$ & & & & & \\
\hline 1 & 6 & 3 & 2 & 1 & 2 & 1 & 1 \\
\hline
\end{tabular}


Megameatus intact prepuce (MIP) has always been one of the challenging conditions among surgeons. It was first described by Juskiewenski. ${ }^{[1]}$ MIP is thought to be a variant of distal hypospadias or subtype of megalourethra. ${ }^{[2,3]}$ When we evaluate the components of MIP it is clearly obvious that there are several differences between MIP and distal hypospadias. Even embriologicalembryological explanations about MIP are suspicious. ${ }^{[2,11,12]}$ Embryological development of MIP can't be explained by the same explanation as distal hypospadias because of the several differences like intact prepuce, wide and thin urethral structure. So obscure in embryological period is one of the reasons why MIP might be categorized separately.

MIP diagnosis is another challenge for clinicians. It's incidence is variable in the literature, being approximately 3\%-6.8\% of hypospadias cases. ${ }^{[7,19]}$ MIP is generally detected after retraction of prepuce during circumcision or might have gone unnoticed because of the difficulty in diagnosis. Neonatologists, primary care physicians and individuals who perform circumcision must be aware of possible penile anomalies even in the presence of intact prepuce. ${ }^{[3]}$ Before any circumcision, prepuce should be carefully retracted, and the glans and meatus must be examined. ${ }^{[3]}$ When MIP is diagnosed, circumcision should be delayed or accomplished depending on surgeon's experience. In our study as in the literature most of the patients were detected at preoperative examination or just before circumcision. So families of previously detected cases and those detected just before circumcisin were informed about the repair.

Determination of MIP anomaly in previously circumcised patient is a special occasion. It is important for surgeon to explain the nature of anomaly appropriately for acceptance of family. Explanation should contain congenital aspect of the condition to make the family realize that it has no connection with circumcision failure. Fahmy et al evaluated 12.518 neonates and infants coming for ritual circumcision to arouse the suspicious for early diagnosis and management of MIP. As a conclusion they argue median raphe anomalies mainly deviation and hyperpigmented prominent raphe to be significant indicators for the presence of an invisible MIP anomaly. ${ }^{[4]}$ Ten patients had raphe anomaly in our study group. None of the patients were circumcised in our study..

Although most of the surgeons prefer surgery some argue to operate this patients or not. ${ }^{[7,8]}$ The goal of the surgery is mostly cosmetic. Especially in societies where the religious circumcision is essential, cosmetically remodeling might be important to avoid child's disturbance. ${ }^{[14,15,19]}$ Cendron ${ }^{[10]}$ reported close localized meatus to the corona or below corona, a deep glans cleft, a wide splayed out glans, abnormal urinary flow are the indicative parameters for surgery. Appearance of intact prepuce directing urine and semen appropirately, absence of chordee, normal micturation, successful parity in MIP are the reasons why some authors do not prefer operation. ${ }^{[6,16]}$ Traditional circumcision is essential in our society. We prefer general anesthesia for circumcision in our clinic and prefer correction of MIP during circumcision. Because all parents prefer this anomaly to be corrected while getting general anesthesis for circumcision.

Today there are various applied techniques in distal hypospadias. ${ }^{[20]}$ The techniques that causes good results in distal hypospadias could not show the same result in MIP. MAGPI and perimeatal based flap techniques that are successfully applied in distal hypospadias might not suitable for MIP. ${ }^{[6]}$ Duckett and Keating ${ }^{[2]}$ described pyramid technique for MIP repair. Pyramid procedure allows for an end -on dissection of the distal megameatus-urethra. This technique doesn't affect calibre also facilitates remodeling of the glans. ${ }^{[2]}$ The GAP was presented for repair of coronal or glanular hypospadias patients especially with a wide and deep groove and fish-mouth meatus. ${ }^{[2,10]}$ Elbatarny et al. ${ }^{[18]}$ reported their MIP series repaired by modified GAP technique. Difference of modified GAP is interposed intermediate layer which prevents overlying suture lines to overlap. Repair with parameatal-based foreskin flap was reported to be successfull by Nonomura ${ }^{[12]} \mathrm{A}$ foreskin flap for urethroplasty is harvested from either the ventral or unilateral site. Parameatal ventral skin is thought to be safely used for MIP repair because ventral portion just proximal to the meatus is well developed and not atretic. ${ }^{[12]}$ The Mathieu technique modification is used to repair MIP too. This technique may offer better anatomic delineation of the urethra and will provide an extra layer for urethral coverage. ${ }^{[10]}$ Techniques used in distal hypospadias surgery are also advisable for MIP repair by some authors ${ }^{[6,7]}$ It wouldn't be rational to represent only one suitable operation type for MIP repair. Suitable operative technique should be tailored after detection of meatal localization. Anatomy of each patient should be evaluated individually. TUPU, TIPU and meatoplasty are the preferred and successfully applied operative techniques by surgeons in our study.

Experienced surgeon is also important for achieving good results. ${ }^{[20]}$ Because of the intact prepuce MIP patients can sometimes be detected after circumcisions done by unexperinced individuals. Despite the opinion that repair of circumcised patients would be more difficult, some authors do not associate this condition with failure of the surgery. ${ }^{[6,21]}$

MIP is generally categorized as a variant of distal hypospadias or subgroup of megalourethra as mentioned previously. But there are appearant differences like intact prepuce, which makes us consider different mechanism from that of most hypospadias cases. Referring to all differences it is possible for MIP to be a unique penile anomaly. Despite well documented studies about additional genitourinary, endocrinological anomalies in all hypospadias cases, we couldn't encounter an article describing the associated anomalies in MIP cases. ${ }^{[13,23]}$

Six of 31 MIP patients (\%20) had genitourinary anomalies in our study. Although the small number of patients is a limitation for this study, according to our results it may be argued that; suspicious embryological theories, number of co-occuring 
genitourinary anomalies, unfavorable consequences after repair techniques, extraordinary anatomical features make MIP a distinctive penile anomaly. Intact prepuce and some author's preference of not to operate these cases can make clinicians think MIP as innocent anomaly. Co-occuring raphe anomalies should arise awareness of MIP among the clinicians who are engaged with the children's medical conditions and also the possible anomalies especially in the societies which circumcision is not traditionally required. Further studies with large number series needed for better understanding of this pathology.

\section{ETHICAL DECLARATIONS}

Ethics Committee Approval: The study was carried out with the permission of Ankara University Clinical Research Ethics Committee (Permission granted: 01.09.2020, Decision no: i7444-20).

Informed Consent: Because the study was designed retrospectively, no written informed consent form was obtained from patients.

Referee Evaluation Process: Externally peer-reviewed.

Conflict of Interest Statement: The authors have no conflicts of interest to declare.

Financial Disclosure: The authors declared that this study has received no financial support.

Author Contributions: All of the authors declare that they have all participated in the design, execution, and analysis of the paper, and that they have approved the final version.

\section{REFERENCES}

1. Juskiewenski S. Vaysse P, Moscovici J. Treatment of anterior hypospadias. (Balanoplasty) (Article in French). J Urol 1983;89: 153-6.

2. Duckett JW, Keating MA. Technical challenge of the megameatus intact prepuce hypospadias variant: the pyramid procedure. J Urol 1989;141: 1407-9.

3. Peretz D, Westreich M. Pseudo-iatrogenic hypospadias: the megameatus intact-prepuce hypospadias variant. Plast Reconstr Surg 2003;111: 11825.

4. Fahmy M, Shenaway A, Altramsy A, Al Samahy O, Yehya A, Othman D. Penile median raphe anomalies as an indicator of megameatus intact prepuce anomaly in children undergoing routine circumcision. Urology 2018;121: 164-7.

5. Fasse MA, Dray EV, Cheng EY. Repair of megameatus: a modified approach. J Pediatr Urol 2015;11:100-1.

6. Bhat A, Bhat $M$, Bhat $A$, Singh V. Results of tubularized urethral plate urethroplasty in megameatus intact prepuce. Indian J Urol 2017;33(4):3158.

7. Bar-YosefY, Binyamini J, Mullerad M, Matzkin H, Ben-Chaim J. Megameatus intact prepuce hypospadias variant. Application of tubularized incised plate urethroplasty. Urology 2015;66(4):861-4.

8. Hill GA, Wacksman J, Lewis AG et al. The modified pyramid hypospadias procedure: repair of megameatus and deep glanular groove variants. J Urol 1993;150: 1208-11.

9. Attalla, FM. Subcoronal hypospadias with complete prepuce: a distinct entity and new procedure for repair. Br J Plast Surg 1991;44: 122-5.
10. Cendron M. The megameatus, intact prepuce variant of hypospadias: use of the inframeatal vascularized flap for surgical correction. Front Pediatr 2018; 6:1-5.

11. Hatch DA, Maizels M, Zaontz MR, Firlitt CF. Hypospadias hidden by a complete prepuce. Surg Gynecol Obstet 1989;169:233-4

12. Nonomura K, Kakizaki H, Shimoda N, et al. Surgical repair of anterior hypospadias with fish-mouth meatus and intact prepuce based on anatomical characteristics. Eur Urol 1998;34: 368-71.

13. Horst HJR, Wall LL. Hypospadias, all there is to know. Eur J Pediatr 2017;176: 435-41.

14. Mureau M, Slijper FM, Nijman RJ, Van der Meulen JC, Verhulst FC, Slob AK. Physosexual adjustment of children and adolescents after different types of hypospadias surgery: a norm-related study. J Urol 1995;154:1902-7.

15. Zoantz MR, Dean GE. Glandular hypospadias repair. Urol Clin North Am 2002;29: 291-8.

16. Bourdoumis A, Kapor S, Bhanot S. Megameatus intact prepuce revisited. Brit J Urol Int 2012; 84:1-5.

17. Docimo S. Subcutaneous frenulum flap (SCUFF) for iatrogenic or primary megameatus and reoperative hypospadias repair. Urology 2001;58(2):271-3.

18. Elbatarny A, Shehata SMK, Ismail K. Megameatus intact prepuce variety of hypospadias: tips for repair using the modified glanular approximation procedure. Ann Pediatr Surg 2011;7: 82-7.

19. Sanal M, Karadag E, Konca Y, Kocabasoğlu U. Megameatus and intact prepuce (MIP) associated with meatal web: a case report. Acta Chir Ausriaca 2000; 32:35-6.

20. Bilici S, Sekmenli T, Gunes M, Geçit I, Bakan V, Isik D. International Urology and Nephrology 43(4), 943-948

21.Zaontz MR. The GAP (glans approximation procedure) for glanular/ coronal hypospadias. J Urol 1989;141: 359-61.

22. Snodgrass WT, Khavari R. Prior to circumcision does not complicate repair of hypospadias with an intact prepuce. J Urol 2006; 176: 296-8.

23. Manzoni G, Bracka A, Palminteri E, Marrocco G. Hypospadias surgery: when, what and by whom? BJU Int 2004;94: 1188-95. 